\title{
Climate change and agriculture management: Western Balkan region analysis
}

\author{
Franc Željko Županić ${ }^{1}$, Danka Radić ${ }^{*}$ and Iztok Podbregar ${ }^{1}$
}

\begin{abstract}
Background: This paper aims to analyze the possibilities of the agricultural sector of the Western Balkan to assess compliance with the European Green Deal, which provides for the implementation of activities, which should enable the transition to sustainable agriculture and climate change mitigation. This paper is among the first to present the causality of agriculture and climate change (status, mitigation, and perspectives) in general and in light of the European Green Deal for the Western Balkan territory.

Main text: Agricultural production is a leading industry in the Western Balkan. Climate change and predictions that temperatures will increase by $4{ }^{\circ} \mathrm{C}$ in the coming decades pose a risk not only to agricultural production but also to the safety of the population, because agriculture is the main source of income for a significant part of it. Uncontrolled floods and droughts caused by climate change are a particular danger for agriculture and human existence. This paper demonstrates that agriculture in the WB can be considered critically affected by climate change.

Conclusions: Unless appropriate measures are taken and risk management for water resources and agriculture is improved, there will be a further decrease in precipitation and an increase in dry days by $20 \%$. Such a scenario endangers not only the already vulnerable climate sustainability and biodiversity of the region but also the existence of a population employed in agriculture and the contribution of the agricultural sector to the gross domestic product. However, future planning based on the Common Agriculture Policy (CAP) and European Green Deal, the adoption of a related regulatory framework, the establishment and regular monitoring of supporting financing mechanisms, regional cooperation, and improving risk management (with emphasis on the local level) can mitigate the present impact and decrease the expected negative impact of climate change on agriculture and biodiversity in the WB region.
\end{abstract}

Keywords: Climate change, Sustainable agriculture, Risk management, Western Balkan countries, European Green Deal

\section{Background}

The Western Balkans region covers an area of about $208,000 \mathrm{~km}^{2}$ and includes the Republic of Serbia, Albania, Bosnia and Herzegovina, Montenegro, and the Republic of North Macedonia. In this area, coastal subtropical to moderately continental climates are

*Correspondence: danka.radic81@gmail.com

${ }^{2}$ Institute of General and Physical Chemistry, Studentski trg 12N, Belgrade, Republic of Serbia

Full list of author information is available at the end of the article represented. Consequently, there is a great variety in the vegetation cover, which is considered the natural wealth of this region. With this in mind, in all WB (Western Balkans countries), agriculture is an important sector with a significant share in the Gross domestic product (GDP, 10\%). In the Republic of Serbia, the total gross value of agricultural production in 2019 amounted to 5.5 billion USD; in Albania, it is the basis of the social wellbeing of the population and the system of protection against unemployment, while in Bosnia and Herzegovina one fifth of the population is employed in this sector. original author(s) and the source, provide a link to the Creative Commons licence, and indicate if changes were made. The images or other third party material in this article are included in the article's Creative Commons licence, unless indicated otherwise in a credit line to the material. If material is not included in the article's Creative Commons licence and your intended use is not permitted by statutory regulation or exceeds the permitted use, you will need to obtain permission directly from the copyright holder. To view a copy of this licence, visit http://creativecommons.org/licenses/by/4.0/. The Creative Commons Public Domain Dedication waiver (http://creativeco mmons.org/publicdomain/zero/1.0/) applies to the data made available in this article, unless otherwise stated in a credit line to the data. 

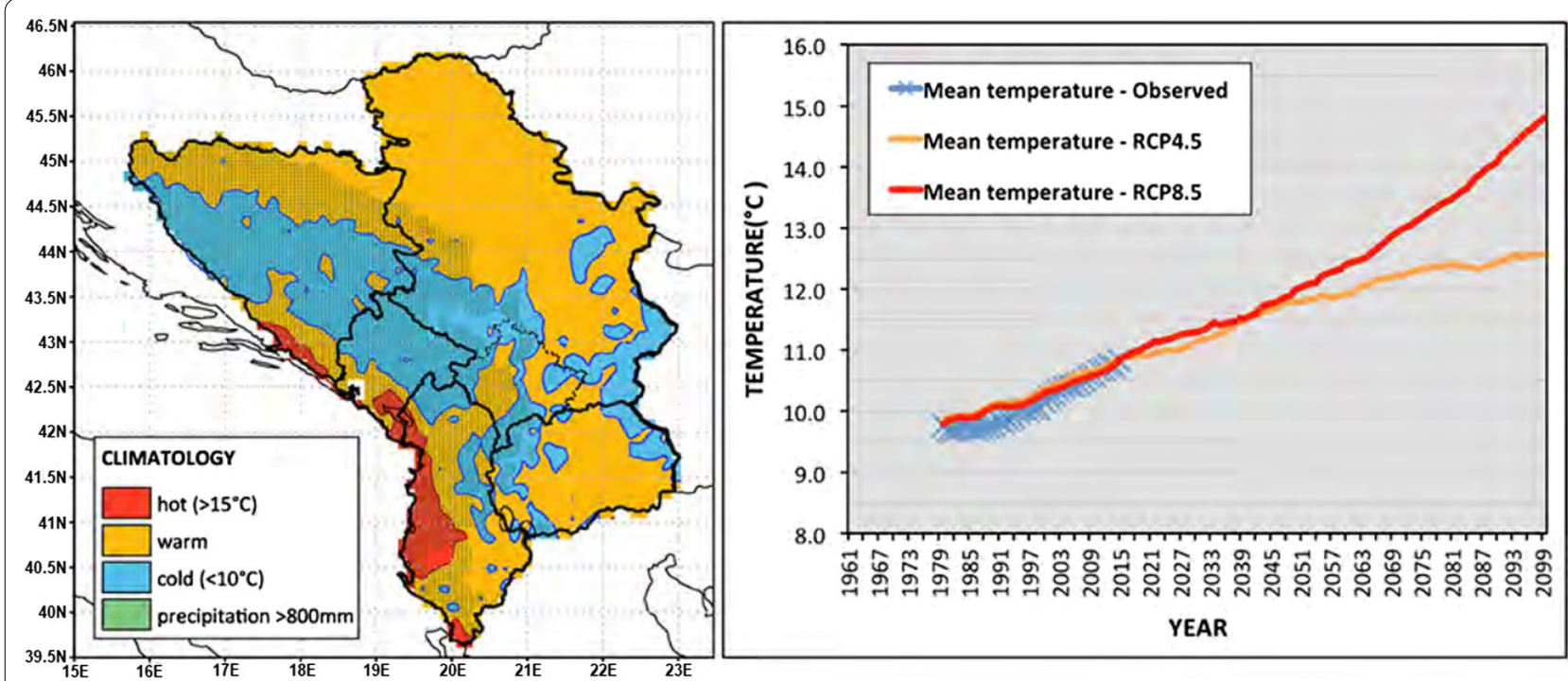

Fig. 1 Climatology of the Western Balkans [2]

Montenegro has a significant share of the agriculture sector in its GDP (8\%), while in the Republic of North Macedonia, agriculture accounts for $13 \%$ of GDP.

However, despite the wealth of natural resources, agrifood systems in all WB countries face several challenges. The agricultural sector is one of the most important sectors, which plays a key role in food production and safety; at the same time, it is responsible for environmental protection, climate change, and gas emissions [1]. In addition, agriculture can be threatened by the impact of many other factors related to climate change (storms, erosion, and landslides caused by climate variability and extreme weather events). Because forestry is important, in addition to agriculture, WB economies are considered medium to highly sensitive to climate change. The main climatological characteristics of the Western Balkan region are shown in Fig. 1 [2].

Figure 1 shows the climatological features of the Western Balkans region with prominent coastal (in red) and mountainous (in blue) areas, as well as areas with temperate and moderately warm climates (in orange). The areas with the most annual precipitation are marked in green. The right panel shows the average annual temperature for the Western Balkans region from 1961 to 2100 (projected) [2]. The "moving average" approach was used to predict average temperatures. Climate change has been recorded for several decades and is a consequence of intensive industrialization and other human activities [3]. Urbanization, deforestation, and the burning of fossil fuels (primarily coal) are the main causes of accelerated and unexpected climate change. In addition, climate change poses serious threats to the environment, ecological, and socio-economic systems [4]. For example, it is predicted that the average summer temperature in the Western Balkan region could rise to $7.5^{\circ} \mathrm{C}$ above preindustrial levels, which would lead to the disappearance of small glaciers within a few decades. This increase in temperature poses a risk not only to agriculture but also to the safety of the population.

Further predictions for the region are that with the warming of $4{ }^{\circ} \mathrm{C}$, precipitation will decrease by $20-30 \%$, and the frequency of dry days will increase by $20 \%$ [5]. Reduced water availability in the summer months could also be a problem, while annual river runoff could be reduced by more than $45 \%$ by the year 2100 . There are also great risks of winter and spring floods, especially along the large rivers, such as the Danube, Sava, and Tisa. It is important to note that the average annual production of large hydropower plants could be reduced by $15 \%$ and $20 \%$ for small power plants.

In addition to all the above facts, there are also great risks to human health: an increase in temperature could increase the number of deaths by about $20 \%$ [6]. Climate change knows no borders and thus contributes to the rapid deterioration of the quality of life and the environment [7]. Reducing damage and losses caused by climate change is not only an environmental but increasingly also a matter of security, the survival of natural resources, and economic development. Reducing the harmful human impact on climate change and its impact on economic and social development is possible by measuring, monitoring, and reporting on the current impact, which is also the subject of regulation of the $\mathrm{UN}$ Framework Convention on Climate Change (UNFCCC) 
and its accompanying Paris Agreement. The direction of European agriculture is particularly important for solving environmental and climate problems; therefore, sustainable development strategies and programs have been implemented for years, which remain insufficient in terms of identified needs [8]. In this context, the European Commission published the European Green Deal (EGD) in December 2019, which is an attempt to transition towards the common goal of a climate-neutral economy by reducing carbon emissions by at least $50 \%$ by 2030 and achieving carbon neutrality by 2050 [9]. From a broader development perspective, the European Green Deal represents a constitutional rationale for environmental protection in the EU legal order, while the focus is on measures affecting the importance of environmental and climate protection for the innovative and economic power of the EU and its Member States [10].

\section{Impact of climate change on Western Balkans agriculture}

Climate change greatly impacts the agricultural sector, especially crop production, livestock, and fisheries [11]. Small parcel size is one of the main obstacles to adaptation/mitigation to climate change. It is important to note that pastures in mountain areas have been abandoned and that the absence of farmers with livestock helps accelerate the spread of invasive species. In those pastures, fires caused by climate change are frequent. Livestock also suffers from climate change, and livestock production is significant in WB. Almost half of the territory of the Western Balkans is used for agriculture, of which $19 \%$ is pasture and $29 \%$ is arable land, while $18-58 \%$ of the workforce is related to this sector [12].

Regarding field and vegetable production, there is stress on plants caused by poor agro-ecological conditions and the inability to apply adequate agricultural practices and technology. The result is reduced yields and product quality, which (among other things) leads to irregularities in the supply chain of raw materials for the food industry. In addition, these changes lead to the appearance of new pests, diseases, and weeds. The problem is microorganisms, plants, and animals that often become invasive and harmful in the new area. In addition, climate change is well tolerated by weeds, because they adapt more easily to changes in the environment [13].

The appearance of weeds (such as ragweed) causes allergies, leads to changes in vegetation and seed reserves in the soil and soil microflora yield reduction and environmental pollution. Compared to conventional production, sustainable agriculture is more vulnerable to the effects of climate change due to the complexity of the different biological, physical, and agrotechnical measures on which it is based. Therefore, Agenda 21 of the UN

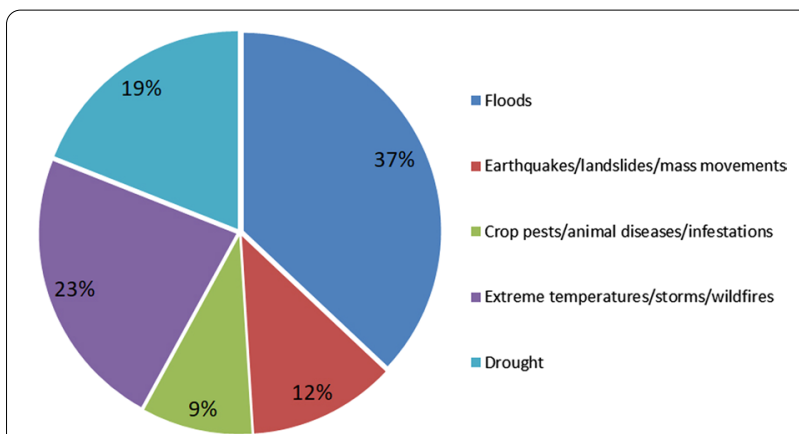

Fig. 2 Losses in crop and livestock production in the 2005-2014 period [16]

Conference on Environment and Development (UNCED) action plan emphasizes the need for adjustment in agricultural, environmental, and macroeconomic policy to create conditions for sustainable agriculture and rural development.

Agricultural biodiversity is extremely important and results from the interaction of the external environment, genetic resources, and the natural resource management system (land and water). Climate change also affects the extinction of certain species, genes, and the reduction or loss of agrobiodiversity. In addition, numerous autochthonous and old varieties, which were adapted to certain areas and ecological conditions, have become endangered. The loss of flora and fauna can lead to permanent changes in an ecosystem and serious disruption of biogeochemical processes. An additional problem is the fact that the crops in Western Balkans are poorly irrigated and that the storage capacities are insufficient. In particular, the increasing occurrence of drought, which mainly occurs in the summer months, has been identified as a key risk for Western Balkan agriculture [14].

Water is a basic natural resource in plant production, because it plays a significant role in germination, growth, transpiration, the transformation of starch into sugar, and the absorption of nutrients [15]. Therefore, the reduction in precipitation poses the greatest danger to the agricultural sector, especially because the demand for food at the global level is increasing. Figure 2 shows the most common natural hazards that cause large losses in crop and livestock production. According to the Center for Research on the Epidemiology of Disasters (CRED) and the Emergency Events Database (EM-DAT), floods have occurred in all Western Balkan countries, leading to large economic losses. In May 2014, catastrophic floods hit the countries of the Western Balkans. Houses, bridges, and parts of roads were destroyed in this natural disaster. The floods devastated the cities and flooded the plowed fields. In Bosnia and Herzegovina, the damage caused by these 
floods was estimated at $15 \%$ of the national income, while in the Republic of Serbia, it was estimated that 11.943 ha of land became unusable. However, observing the average values of annual economic losses, it was found that the damages caused by floods ( 38.75 and 106.25 million euros) are much less than the damage caused by drought (500 million euros) [16] (presented in Fig. 2). It is important to note that there are no accurate and reliable data on the impact of drought and floods on the Western Balkan agricultural sector. Such data are extremely important, because they are used to measure the effectiveness of disaster risk reduction investments.

Given that precipitation reduction is expected due to climate change, water management will be essential for the stability and productivity of agricultural production. For example, a regional analysis showed that extreme temperature changes in 2011 led to crop failure due to frost damage [17]. Indirectly, drought significantly impacts the economy, prices, and food supply, bearing in mind that the agricultural sector suffers the greatest consequences. For example, if the supply of a certain vegetable decreases and the demand still exists or increases, there will be an increase in the product's price. An example of this is the drought in Tajikistan (2007-2008) which reduced yields by over $40 \%$ [18], which led to 2.2 million people being malnourished [19]. Moreover, drought directly increases the risk of fire.

From 1998 to 2008, 853 forest fires broke out in the Republic of Serbia, covering an area of 16.357 ha. The damage caused by the fires was estimated at 40 million euros, and more than 5.200 ha were completely burned [20]. The existence of a connection between drought and pests has also been determined due to the creation of optimal conditions for their development. Some diseases are directly caused by the stress of plants caused by drought, such as root rot, rot and wilting of trees, and greater susceptibility to flamingos. Stressed woody plants can experience the invasion of woody insects, such as bronze birch, black stem, and other bark beetles [21]. In addition, drought can reduce the competitiveness of indigenous plants and increase the chances of weed invasion and thus negatively affect crop production [22].

According to the international CRED-EMDAT disaster database, floods occurred most frequently in Western Balkans resulting in significant economic losses. However, the negative impact of drought should not be underestimated, although accurate data are often lacking due to the lack of systematic and comprehensive data collection. As for Albania, it is estimated that more than three million people were affected by the drought between 1989 and 1991, which is considered one of the most significant disasters, and cost this country's economy 24 million USD [23]. Furthermore, the energy crisis that led to power outages in 2007 resulted from droughts, because the production of the Fierza hydropower plant was lower by $33 \%$ [24].

Drought is predicted to have a more negative impact on agriculture than floods and landslides. Different areas in Bosnia and Herzegovina are prone to drought, especially between June and September. Some of the most significant droughts that affected this country were from 2002 (agricultural production was reduced by 60\%), 2003 (agricultural damage of 200 million USD), and 2007 (destroyed more than $40 \%$ of field production, 250 ha affected by forest fires, which increased food prices). In 2012, a drought hit the Western Balkans, especially Bosnia and Herzegovina. It reduced grain and vegetable yields by up to $70 \%$, and corn production was most affected. Given the large primary losses in barley, corn, soybean, clover, and beans, livestock production decreased, as did meat supply to the domestic market, increasing food prices and reducing agricultural exports. The total losses of this drought amounted to over 1 billion USD [25]. Frequent and intense droughts adversely affect yield quality and the costs of preventing and controlling the spread of diseases, insects, weeds, and irrigation rates.

Furthermore, it is estimated that the agricultural sector was most affected by the drought in 2015 when water balance anomalies were $100 \mathrm{~mm}$ below the long-term average [26]. However, accurate data on specific damage and losses are missing. The Republic of North Macedonia is considered to be among the driest countries in Europe. The most endangered are the region of Povadarija, and especially the areas of the rivers Crna, Bregalnica, and Vardar. The 1993 drought was estimated at $7.6 \%$ of total national income and led to a complete decline in crops [27]. According to the second statement of the Montenegrin Ministry of Sustainable Development and Tourism on climate change from 2015, several droughts have been recorded since 1950. The agricultural drought recorded in 2003 affected the coastal region, the Zeta-Bjelopavlić region, and the northern region up to $1000 \mathrm{~m}$ above sea level. The 2007 drought is considered a hydrological drought and has affected the entire territory, especially the northwestern and northern mountainous regions, while the 2011 drought is considered a social and economic drought. The last recorded drought affected the entire country and led to an extreme hydrological deficit in the Zeta Bjelopavlići region [28]. These extreme conditions led to forest fires the following year.

In the previous two decades, three catastrophic droughts have occurred in the Republic of Serbia. From 1991 to 2010, the extremely dry years were: 1992, 1993, 1998, and especially 2000, 2003, and 2007 [29]. The most 
endangered areas are in the eastern part and the Pannonian Basin in the northern part of the Republic of Serbia. From April to September 2009, a severe drought hit Sremska Mitrovica [30]. During the summer of 2012, a drought caused losses in agricultural production of about two billion USD. The largest losses were in corn (1 billion USD), sugar (130 million USD), soybeans (117 million USD), fruits and vegetables (100 million USD), sunflowers ( 55 million USD), and other crops (600 million USD) [31]. According to a 2013 report by WMO, UNCCD, FAO \& UNW-DPC, economic losses in agriculture are estimated to be caused by floods between 38.75 and 106.25 million euros, while for drought, they were around 500 million euros [32]. These data indicate that the impact of drought on agriculture is much greater compared to floods. However, it should be noted that due to insufficient available data on losses and damages in agriculture caused by drought, one can only speak at the level of assessment.

\section{Response to climate change in the Western Balkans}

The Western Balkans are already taking appropriate measures to reduce the harmful effects of climate change, including cooperation with several development partners. These measures include managing risks to water resources and agriculture, as well as using opportunities to achieve energy efficiency and modernize infrastructure. Table 1 shows the laws adopted thus far, as well as measures to reduce the harmful effects of climate change on Western Balkan agriculture.

The Republic of Serbia has adopted the Law on Climate Change, which obliges it to fulfill its obligations arising from its membership in the Energy Community, as well as all other obligations by which the Republic of Serbia harmonizes its legal framework with the EU acquis in the field of climate change, environment, and energy (EU Climate Law). Furthermore, the Parliament of Albania passed a law on climate change, which envisages the submission of national targets for contributing to reducing greenhouse gas emissions in accordance with the United Nations Framework Convention on Climate Change (UNFCCC). Other Western Balkan countries have also adopted laws to protect against the harmful effects of climate change, reduce greenhouse gas emissions, and protect the ozone envelope. The main obstacles to implementing these laws are reflected in participation, accountability, transparency, integrity, connectivity, and knowledge, which are key criteria in climate change management.

Given that one of the biggest problems of Western Balkan is drought, all measures taken are aimed at applying technologies that achieve prevention and mitigation of consequences. In recent years, various projects that aimed to reduce the harmful effects of drought have been implemented on the territory of the Western Balkans. The Agriculture Project Water Resources and Drought Mitigation Strategy in the Western Balkans (WATERWEB) was aimed at strategic water management and mitigating the effects of drought on sustainable agricultural practices. The project was funded by the European Commission (FP6) in 2004-2006 and involved four EU countries and three Western Balkan partners (Republic of Serbia, Montenegro, and Republic of North Macedonia). As the region of Southeast Europe is also prone to drought, 13 countries have established the Center for Drought Management in Southeast Europe (DMCSEE). This center aims to improve drought preparedness, conduct vulnerability and risk assessments, and establish an early warning system to reduce the effects of drought. The DriDanube project is funded by the EU and aims to strengthen the capacity of the Danube region and improve the response to drought emergencies. In addition to nine EU countries, Western Balkan countries (the Republic of Serbia, Bosnia and Herzegovina, and Montenegro) are also participants. It is important to note that Western Balkans emphasize the importance of enhanced cooperation between decision-makers, the scientific community, investors, the private sector, and farmers. Continuous monitoring and reporting on soil moisture and crop condition are keys in the fight against drought. However, a major Western Balkan stimulus is needed to meet the challenge of climate change fully. Investment policy decisions will significantly affect the intensity of carbon emissions and climate change in general. Bearing in mind Western Balkans' geographical and economic interconnectedness, many issues related to adaptability, water resources management, and energy infrastructure will be a particular challenge.

\section{EU and climate change, EU Green Deal}

Climate change is one of the key issues of the $\mathrm{EU}$, and the adoption of the European Green Deal speaks in favor of that. This agreement aims to reduce the harmful impact on natural resources and emissions into the soil, water, and air. It also represents a strategic framework according to which the challenges of climate change and environmental protection are transformed into development potentials. The EU expects that carbon neutrality will be achieved by 2050, and Western Balkan's assistance is expected [33]. Starting in 2021, the introduction of carbon taxes on products (iron, cement, and aluminum) imported into the EU is also expected, and with the aim of expanding to other economic branches and activities. Thanks to this initiative, the competitiveness of products from countries without a clear action plan against climate change is reduced. The European Green Deal is based on: 


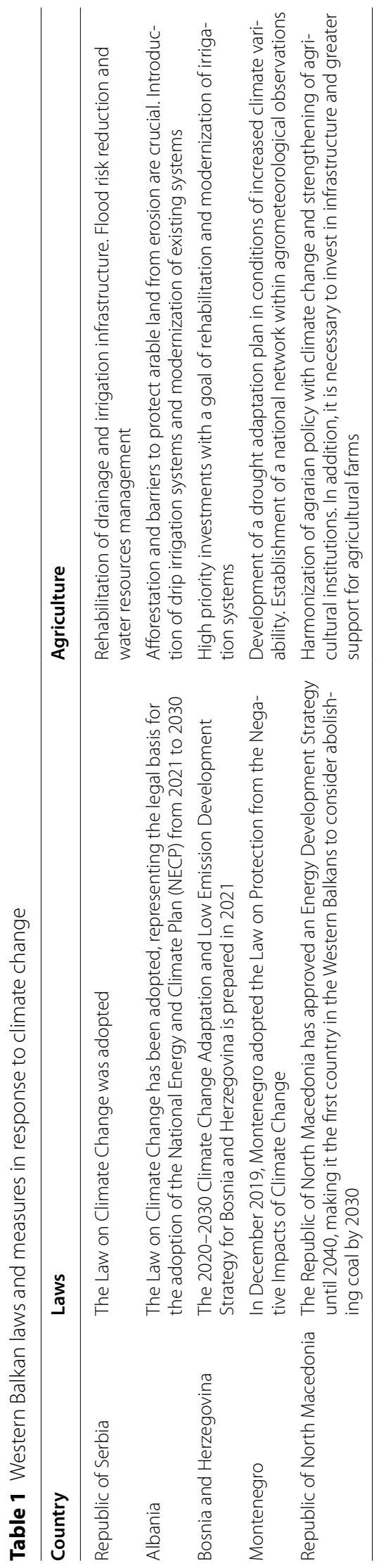


(1) climate action involving decarbonization, energy, and mobility; (2) the circular economy with special emphasis on waste, recycling, and the efficient use of resources and sustainable production; (3) biodiversity aimed at protecting and restoring natural resources; (4) reduction of water, soil, and air pollution and (5) sustainable food systems and rural areas.

The basic driver that will enable all of the above is digitalization in accordance with the concept of the double green and digital transition. It is also necessary to implement concrete actions supported by appropriate mechanisms and financial instruments. Five Western Balkan partners have ratified the Paris Agreement, pledging to take measures to limit global warming to $1.5^{\circ} \mathrm{C}$. Climate neutrality will have a significant impact on EU bilateral relations and accession negotiations with the Western Balkans. One of the important tools for creating economic stimulus and helping to mitigate the transition to climate neutrality may be the early involvement of the Western Balkans in emissions trading. All these changes will require the support and involvement of citizens. According to research from 2019, only 65\% of Western Balkans citizens consider climate change a threat [34], unlike EU citizens, where $93 \%$ consider climate change a serious problem [35]. For example, the citizens of the Republic of North Macedonia will most likely hold the state responsible (31\%), while Albanian citizens believe that companies are most responsible for combating climate change (27\%). An interesting fact is that Montenegrins believe that they are personally responsible for climate change compared to the representatives of any other economy in the region. It is important to point out that the European Climate Pact could be a means of raising awareness among citizens.

Given the EU's mechanisms for cross-border adjustment of $\mathrm{CO}_{2}$ emissions (CBAM), it is necessary to point out that the EU will continue to support the countries of the Western Balkans in implementing the Green Agenda and the development of carbon pricing policies. Over the next 7 years, the economic investment plan envisions a substantial $€ 30$ billion investment package for the region. Of that, $€ 9$ billion are in the form of grants and $€ 20$ billion in investments, duo to the financial leverage of the new Guarantee Instrument for the Western Balkans. To achieve the maximum effect of the economicinvestment plan, the countries of the Western Balkans must resolutely implement economic and social reforms and strengthen the rule of law. The leaders of the Western Balkans are expected to make more decisive efforts to fulfill all obligations regarding the establishment of a common regional market, which was agreed at the summit of the Berlin Process in Sofia in 2020. Thanks to the support of the EU and the economic-investment plan, a long-term impact on the green socio-economic recovery and competitiveness of the region is intended through the supporting of green and digital transition to increase cooperation and convergence with the EU.

\section{Climate change management}

There are different approaches to managing climate change risks, which can be divided into four categories: (1) mitigation to reduce greenhouse gas emissions; (2) adaptation, which means increasing society's ability to cope with climate change; (3) geoengineering, which implies additional manipulations of the soil system, to reduce the impact of greenhouse gas emissions and (4) expanding the knowledge base on climate systems, which can help in proactive risk management [36].

Of particular importance are research, observations, scientific assessments, and the development of technology that can help identify risks and opportunities associated with climate systems. Expanding the knowledge base enables policymakers to understand, select and improve the management of certain risks more effectively. Thanks to such an approach, efficiency is increased, and new possibilities for climate protection or reducing the risk of climate change are discovered. It should be noted that climate goals can be achieved with the active participation of all state bodies [37]. Although local governments are increasingly paying attention to climate change, the problem is that their policies focus on mitigation and not on climate change adaptation strategies [38]. To respond to climate change as successfully as possible, adaptation is necessary, which includes planning for climate impacts, building resilience to those impacts, and increasing society's ability to respond and recover [36].

Adaptation policy may include various regulations, such as the reduction of harmful impact on the soil, disaster recovery, impact assessment for critical systems and resources (water, biological systems, agriculture, and infrastructure), constant monitoring, and efforts to reduce air pollution, soil loss, and degradation [39]. Regarding Western Balkan countries, the exchange of expertise and division of responsibilities at the regional level are the best measures for capacity building and identification of measures for climate change management. Furthermore, to ensures the health of the population, safety, and quality of life, including the development of warning systems, timely dissemination of information, and general preparedness of public opinion, as well as the readiness of state institutions to manage disaster risk, are necessary. 


\section{Conclusions}

Agriculture is an inseparable part of the environment and, as such, it is affected by all meteorological, water, or land anomalies. Regarding climate change, all segments of agricultural production will be endangered, especially crop production. The negative impact on plant and livestock production will also affect the food industry and thus the regularity in the supply chain of raw materials. All this leads to economic and social insecurity.

In addition to climate change mitigation activities, the need to develop adaptation systems (i.e., adaptation to changed climate conditions) has become necessary. In accordance with all the above, the innovation of this paper is focused on the subject of research, about which there are very few studies, data are not updated, and there are only estimates of the negative impact of drought on agriculture, while scientific studies by authors from the region are rare. Theoretical research and analysis are supported by data from official reports, academic literature, relevant articles, publications, and relevant state documents of the Western Balkans. Therefore, the analysis of data in this paper that indicates the possibility of the agricultural sector of the Western Balkans and harmonization with the European Green Deal to mitigate climate change is extremely important. The countries of the Western Balkans are in the process of joining the European Union, which, among other things, requires countries to harmonize their policies, especially with the EU legislative framework on climate change, which focuses on actions in the energy sector.

Therefore, the implementation of the EU Green Deal will require significant public and private funding, nationally, regionally, and internationally. Negotiations on external instruments are underway within the next EU Multiannual Financial Framework (MFF, 2021-2027) with the European Council and the European Parliament. To fill a significant investment gap, private funding is also necessary, in addition to public funding from the EU. Finally, education is key to preserving the environment and must include a curriculum and acquiring skills that will enable the implementation of the European Green Deal.

\section{Acknowledgements}

Not applicable.

\section{Authors' contributions}

DR prepared the concept of the study, participated in data collection, analysis, and interpretation of the results. All authors read and approved the final manuscript.

\section{Funding}

This research was supported by the Slovenian Research Agency: Program No. P5-0364-The Impact of Corporate Governance, Organizational Learning, and Knowledge Management on Modern Organization.

\section{Availability of data and materials}

The data sets used and/or analyzed during the current study are available from the corresponding author on reasonable request.

\section{Declarations}

Ethics approval and consent to participate

Not applicable.

\section{Consent for publication}

Not applicable.

\section{Competing interests}

The authors declare that they have no competing interests.

\section{Author details}

${ }^{1}$ Faculty of Organizational Sciences, University of Maribor, Kidričeva cesta 55a, Kranj, Slovenia. ${ }^{2}$ Institute of General and Physical Chemistry, Studentski trg 12 N, Belgrade, Republic of Serbia.

Received: 7 August 2021 Accepted: 6 December 2021

Published online: 16 December 2021

\section{References}

1. Tsangas M, Gavriel I, Doula M, Xeni F, Zorpas AA (2020) Life cycle analysis in the framework of agricultural strategic development planning in the Balkan Region. Sustainability 12:1813. https://doi.org/10.3390/su120 51813

2. Vuković A, Vujadinović Mandić M (2018) Study on climate change in the Western Balkans region. Regional Cooperation Council Secretariat. Printline d.o.o., Sarajevo, Bosnia and Herzegovina. ISBN: 978-9926-402-09-9

3. Božanić D (2020) Analysis of the legislative framework of climate change. Secretariat of the Informal Green Parliamentary Group. Belgrade Fund for Political Excellence (BFPI). file:///C:/Users/asus/Downloads/Analizazakonodavnog-okvira-klimatskih-promena-u-Srbiji-1\%20(1).pdf. Accessed 20 May 2021

4. Gomes CTMR (2019) The European Union accession and climate change policies in the Western Balkan countries. In: Reis L, Sequeira T (eds) Climate change and global development. Contributions to economics. Springer, Cham. https://doi.org/10.1007/978-3-030-02662-2 8

5. Sekulić G, Dimović D, Kalmar KJZ, Todorović N (2012) Procena ranjivosti na klimatske promene-Srbija. WWF (Svetski fond za prirodu), Centar za unapređenje životne sredine. ISBN 978-86-915643-0-8

6. Božanić D, Mitrović Đ (2019) Studija o socio-ekonomskim aspektima klimatskih promena u Republici Srbiji. Program Ujedinjenih nacija za razvoj. file:///C:/Users/asus/Downloads/Nacrt20Studije20o20Socioekonomskim20aspektima20klimatskih20promena20u20Republici20Srbiji. pdf. Accessed 01 Nov 2021

7. Vulevic A et al (2021) Cross-border cooperation and adaptation to climate change in western Balkans Danube area. In: Berisha E, Cotella G, Solly A (eds) Governing territorial development in the Western Balkans. Advances in spatial science (The Regional Science Series). Springer, Cham. https://doi.org/10.1007/978-3-030-72124-4_14

8. Wrzaszcz W, Prandecki K (2020) Agriculture and the European Green Deal. Probl Agric Econ 365(4):156-179. https://doi.org/10.30858/zer/13184

9. Sikora A (2021) European Green Deal_-legal and financial challenges of the climate change. ERA Forum 21:681-697. https://doi.org/10.1007/ s12027-020-00637-3

10. Hainsch K et al (2020) Make the European Green Deal real: combining climate neutrality and economic recovery, DIW Berlin: Politikberatung kompakt, 153. ISBN 978-3-946417-44-6, Deutsches Institut für Wirtschaftsforschung (DIW), Berlin

11. Stričević R, Prodanović S, Đurović N, Petrović OO, Đurović D (2019) Influences of climate change on Serbian agriculture. United Nations Development Program. ISBN: 978-86-7728-262-2

12. Abramović $V$, Jacimović $D$, Jocović M (2016) Klimatske promjene i njihov uticaj na zemlje regiona. Ekonomske ideje i praksa 
13. Kumar Rai P, Singh JS (2020) Invasive alien plant species: their impact on environment, ecosystem services and human health. Ecol Indic 111:106020. https://doi.org/10.1016/j.ecolind.2019.106020

14. Gocic M, Trajkovic S (2014) Spatiotemporal characteristics of drought in Serbia. J Hydrol 510:110-123

15. Filipović A (2020) Water plant and soil relation under stress situations. IntechOpen. https://doi.org/10.5772/intechopen.93528

16. FAO (2017) The future of food and agriculture — trends and challenges. Rome. ISBN 978-92-5-109551-5

17. Regional Environmental Center for Central and Eastern Europe (2011) The impacts of climate change on food production in the Western Balkan Region. Szentendre, Hungary

18. CAREC (2015) Tajikistan: Country situation assessment. Working paper. Almaty

19. FAO (2008) FAO's Role in the $2008 / 2009$ Humanitarian Food Security Appeal for Tajikistan. Rome. http://www.fao.org/fileadmin/user_upload/ emergencies/docs/tajikistan_appeal_2008_2009.pdf

20. Aleksić P, Krstić M, Janćić G (2009) Forest fires_ecological and economic problem in Serbia. Bot Serbica 33(2):169-176

21. Kujawski R (2011) Long-term drought effects on trees and shrubs. UMassAmherst. The Center for Agriculture, Food and the Environment

22. Australian Government (2017) Factors influencing weeds. http://www. environment.gov.au/biodiversity/invasive/weeds/weeds/why/factors. html. Accessed 17 March 2021

23. UNDP (2015) Climate change and disaster risk reduction snapshot. Albania, Istanbul

24. Laska MA, Mustaqi V, Jaupaj O, Como E, Bardhi A, Dvorani M (2012) Droughts and their impact on the Albanian Territory. Agric For 58(1):7-17

25. Zurovec O, Vedeld OP, Kumar Situala BK (2015) Agricultural sector of Bosnia and Herzegovina and climate change-challenges and opportunities. Agriculture 5:245-266

26. ICPDR (2015) The 2015 droughts in the Danube River Basin. Vienna

27. WMO (2012) Strengthening multi-hazard early warning systems and risk assessment in the Western Balkans and Turkey: assessment of capacities. Gaps and Needs, Geneva

28. Ministry of Sustainable Development and Tourism (2015) The Second National Communication on Climate Change. Podgorica

29. WMO/UNCCD/FAO \& UNW-DPC (2013) Country Report. Drought conditions and management strategies in Serbia. Initiative on Capacity Development to support National Drought Management Policy, Belgrade

30. Duričn S, Bodrož D (2013) The impact of drought on yield position of the group enterprises from agricultural sector. Econ Agric 1:25-37

31. USDA Foreign Agricultural Service (2012) Drought driven declines in Serbian crops increased food prices. Global Agricultural Information Network. Belgrade

32. WMO/UNCCD/FAO \& UNW-DPC (2013) Country Report Drought conditions and management strategies in Serbia. Initiative on capacity development to support National Drought Management Policy. Belgrade

33. Beogradski fond za političku izuzetnost (2020) Analiza zakonodavnog okvira klimatske promene. Sekretarijat neformalne Zelene poslaničke grupe

34. Balkan Barometer (2019) https://www.rcc.int/pubs/89/balkan-barometer2019-public-opinion-survey. Accessed 17 April 2021

35. Special Eurobarometer 490 (2019) Climate change report. https://ec. europa.eu/clima/sites/clima/files/support/docs/report_2019_en.pdf. Accessed 17 April 2021

36. Higgins PAT (2014) Climate change risk management. An AMS Policy Program Study. The American Meteorological Society, Washington, DC

37. Dobravec V, Matak N, Sakulin C, Krajačić G (2021) Multilevel governance energy planning and policy: a view on local energy initiatives. Energ Sustain Soc 11:2

38. Hoppe T, van den Berg M, Coenen F (2014) Reflections on the uptake of climate change policies by local governments: facing the challenges of mitigation and adaptation. Energy Sustain Soc 4:8

39. Stupak I, Mansoor M, Smith CT (2021) Conceptual framework for increasing legitimacy and trust of sustainability governance. Energ Sustain Soc. https://doi.org/10.1186/s13705-021-00280-x

\section{Publisher's Note}

Springer Nature remains neutral with regard to jurisdictional claims in published maps and institutional affiliations.
Ready to submit your research? Choose BMC and benefit from:

- fast, convenient online submission

- thorough peer review by experienced researchers in your field

- rapid publication on acceptance

- support for research data, including large and complex data types

- gold Open Access which fosters wider collaboration and increased citations

- maximum visibility for your research: over $100 \mathrm{M}$ website views per year

At BMC, research is always in progress.

Learn more biomedcentral.com/submissions 